\title{
Website-Based Interactive Media to Expand Guidance and Counseling Services for Adolescent
}

\author{
Harlina* \\ Universitas Sriwijaya \\ Palembang, Indonesia \\ harlina_zam@yahoo.co.id*
}

\author{
Rani Mega Putri \\ Universitas Sriwijaya \\ Palembang, Indonesia \\ rani@konselor.org
}

\author{
Chreisna Lapriyandi \\ Universitas Sriwijaya \\ Palembang, Indonesia \\ chreisnalapriyandi@gmail.com
}

\begin{abstract}
This research aimed to develop a website based interactive media which was feasible and efficient to expand and make easier the services delivery of guidance and counseling process. The website would be easier to be accessed and realtime without time limitation. The research approach was developmental research and applying ADDIE model. The result shows that interactive media is expected to be used for general purposes in guidance and counseling delivery services.
\end{abstract}

Keywords-guidance and counseling, interactive media

\section{INTRODUCTION}

Living in an era of technology in which technology developed a social network. Social networking is a software that allows us to communicate and meet with people in the world faster and easily. Social networks, in general, have a broad impact on its users. According to one website called Hootsuite, data on social media users in 2019 have reached 3.4 billion, 3.2 billion people who use smartphones. And the highest platform is Facebook and the second is YouTube.

Users of social networks in Indonesia reached 150 million users from 256 million people in Indonesia, this number reached $56 \%$ of the total population in Indonesia. $91 \%$ of people use mobile phones and $60 \%$ use smartphones. The average internet usage reaches 8 hours 36 minutes every day and 3 hours 26 minutes for social media usage. Source www.datareportal.com. While 130 million active users use social media with their smartphones this number reaches $48 \%$ of the population in Indonesia. The average user ranges from 18-34 years old male and female.

The frequency of internet usage in Indonesia for daily usage reaches $76 \%$, once a week $14 \%$, once a month $6 \%$, and users at least once a year reaches $1 \%$. The amount of time spent on social networks is even higher than in previous years.

One social media that is often used is Facebook. This social network has a high level of interest, Facebook occupies the 3 most use of social media after YouTube and WhatsApp. According to data on Facebook usage in Indonesia reaches 130 million users.

Based on those data we can conclude that the use of the internet in Indonesia is huge and time-consuming users. The time spent surfing the internet is only for social networking activities. Because of the time used 8 hours a day is only to open social networking. Therefore, making interactive media based on counseling guidance website can easily reach counselees who well-understand the virtual world, to be more active in developing guidance and counseling. Because it is time for counseling to advance to a stage that is more easily accessible by the counselee and will make the counselee increasingly receive the benefits of counseling itself.

Media is a tool or means used to convey messages from communicators to the public. Some psychologists view that in communication between humans, the most dominating media in communication is the human senses such as the eyes and ears. The messages received by the senses are then processed by the human mind to control and determine their attitude towards something before it is stated in action [1].

Interactive Media is one of the media that can be used for guidance and counseling services, especially targeting students in secondary schools. According to Seels and Glalgow [2] that interactive media is a media delivery system that presents recorded video material with computer control to the audience (students) who not only hear and see video and audio but also provide responses that are active and response that determines the speed and sequence of presentation. Interactive media has an audio-visual element (including animation) and is called interactive because this media is designed to actively involve the user's response.

Besides, according to the Big Indonesian Language Dictionary (KBBI) interactive media is an intermediary tool or liaison related to computers that are mutually interrelating and mutually active. The most important characteristic of this media group is that students not only pay attention to the media or objects but they are also required to interact while attending guidance and counseling services.

There is an interaction that shows students interacting with a program, for example being asked to fill in questionnaires or inventory in a particular application program using a computer. Through this interaction, students are finally able to hold back and solve their problems, for example, interest understanding programs, self-development programs, interactive counseling programs, and so on.

Manage interactions between students regularly; for example, various game or group dynamics used in group guidance, classical guidance and group counseling. So it can be concluded that interactive media is an intermediary tool designed with the use of computers using elements such as sound (audio), images (visual), and text to convey a message within the scope of guidance and counseling activities. 
The media to be developed is website-based interactive media, because website-based interactive media is very easily accessed by all groups, including school students, students, and even office employees and housewives. The media can also be accessed in realtime or 24 hours which will give you the breadth of accessing the page they can access in their free time without interrupting other work. Another reason is interactive media is not only an active counselor but counselors/students take part in developing media so that they can experience directly the learning experience itself. This will be interesting for them because of the interaction directly with the material provided by the counselor.

Information technology that is currently developed use among adolescents has profitable to adolescents. Using this technology, adolescents can communicate with other users from all over the world, exchange information quickly, and facilitate the learning process.

In the field of culture, having an identity is indeed a basic process for everybody. The globalization era that has taken place in the last few decades is considered to have a dual impact on the formation of cultural identity. The process of cultural globalization allows the encounter or crossing of cultures from cultures that come from various parts of the world and are interconnected with one another. On the one hand, this is considered to interfere with the formation of identity, but on the other hand, it causes the emergence of "multiple cultural identities", namely the inclusion of two identities in the same individual: local culture and global culture [3].

This identity implies an orientation towards the way a person sees himself concerning others, which in turn influences his behavior in social situations. The identity of adolescents who use slang language on social media represented their orientation in viewing themselves. Cultural identity is created by exchanging messages between people who interact (interactants); it is a certain character of the group communication system that arises in special situations. In this view, communication is the meaning in which individuals and groups negotiate, create together, strengthen, and express their cultural identity.

The assertiveness or portraying an identity becomes the basis for a communicative perspective on cultural identity. When an individual recognizes a cultural identity, he identifies himself with a cultural group and confirms his membership. As confirmed by Rotheram and Phinney (1987), reference groups are groups in which a person chooses consciously to imitate [4].

In other words, identity is expressed when the reference group is attached to one person by another person as well as the cultural identity recognized by that person.

The findings reinforce the explanation 'how language, culture, and technology can join and influence communication among adolescents. Adolescents who adopted slang language on social media must have a certain motive. Motive can be interpreted as a "Driving Force" that moves people to behave and act with a specific purpose. Moekijat said, "Motive is an understanding that contains all the driving forces for reasons or impulses in humans that cause it to do something" [4].

\section{METHODS}

This research was applying ADDIE (analysis, design, development, implementation, and evaluation) model. The analysis was based on interviews and observation of real situation at Srijaya Negara High School, concerning students need assessment and service delivery of guidance and counseling. Then interactive media was developed with the subject of self-adaptation. This activity was considered so that the media could be used by counselors and students. The next step was applying the media in the delivery service to get responses from students. Finally, the developed interactive media was being evaluated to find out comprehensive information about the media, considering the strength and weakness of the interactive media.

\section{RESULT AND DISCUSSION}

Need assessment of students showed that self-adaption was an important thing to be fulfilled. Some of the students tended to be alone in break time, were not involved in-class activities, and some to be on verbal bullying without the capability to be assertive. Therefore, the subject matter of self-development, assertive, and think positive were chosen in service delivery. These subject matters could be accessed by students through interactive media.

Validation of media was doing a readability test by school counselors, therefore the media could be used by students and operated by school counselors. The step of implementation was conducted in a small group of counselors and they stated that the media could be implemented by school counselors. The last step was evaluation which was considered for comprehensive useage aspects of interactive media. Though the media could be implemented there were some obstacles for the school counselor to deliver the guidance and counseling services. The obstacles were related to time as a major obstacle, the second one was the incidental condition as counselors were delivering the services, and the third was an internet network to access the web.

Despite the obstacles faced by the school counselors, but they could take advantage of the interactive media which was developed. The media have fulfilled the qualification of 'user-friendly', including easy to respond and to access as desire, as well as the use of language that were simple and easy to understand. The evaluation giving by experts concerning performance, implementation steps of the school counselor, subject matter, and language use met eligibility. These all steps of developing interactive media would strengthen the media eligible to be used.

The usability level of interactive media was high, regarding $87,53 \%$ mean score at a high level. It meant that school counselors capable to practice the media. This condition was relevant to Dharma that media as learning facilities which were designed systematic and interesting to achieve expected competencies [5]. The school counselor was a facilitator who helped students to be independent and learn at their speed. 


\section{CONCLUSION}

The media was a tool for providing guidance and counseling services. Using technology was assisting the guidance and counseling process. Based on steps to develop media in which the subject matter of self-adaptation, the interactive media was considered as a feasible and useful medium for delivering guidance and counseling services to high school students. The students are adolescents who familiar with websites. In short, this interactive media could be used by school counselors to help students to develop their own needs.

For the advance steps, it was needed to validate media as a prototype being implemented to students of Srijaya Negara High School. Indeed, the prototype was validated in a small group of school counselors. It was needed for a field validation to evaluate the effectiveness of media usage, and adjusted to student's needs.

\section{REFERENCES}

[1] Cangara, Hafid. 2006. Pengantar Ilmu Komunikasi. Jakarta: Raja Grafindo Persada.

[2] Sofah, Rahmi and Sigit Dwi Sucipto,. 2017. Teknologi Informasi dan Media Bimbingan Konseling, Palembang, Noerfikri.

[3] Ana Puji Astuti, Anike Nurmalita Rps. (2014). Teknologi Komunikasi Dan Perilaku Remaja. Jurnal Analisa Sosiologi.

[4] Molenda, Michael. 2003. "In Search of the Elusive ADDIE Models".

(Online),(http://www.comp.dit.ie/dgordon/Courses/ILT/ILT0004/InSea rchofElusiveADDIE.pdf, diakses 27 Juni 2012).

[5] Dharma, Surya, 2008. Pendekatan,Jenis dan Metodologi Penelitian Pendidikan. http://www.scibd.com/doc/20980578/penelitian. 